\title{
Effect of Thidiazuron Used as an Elicitor in the Production of Capsaicin on Total Protein and Phenolic Amounts, Antioxidant Enzyme Activities of Pepper Plants
}

\author{
Cemil Islek ${ }^{1}$, Bengu Turkyilmaz Unal ${ }^{1 *}$, Esra Koc ${ }^{2}$, Dilek Kaya ${ }^{3}$ \\ ${ }^{1}$ Omer Halisdemir University, Arts and Sciences Fac., Biotechnology Dept., 51240 Nigde, Turkey \\ ${ }^{2}$ Ankara University, Sciences Fac., Biology Dept., 06100 Ankara, Turkey \\ ${ }^{3}$ Omer Halisdemir University, Arts and Sciences Fac., Biology Dept., 51240 Nigde, Turkey \\ *e-mail:bturkyilmaz@nigde.edu.tr, tel: +903882254035, fax: +903882250180
}

\begin{abstract}
The effect of thidiazuron (TDZ) used as an elicitor on the total phenolic, total protein, superoxide dismutase (SOD) and catalase (CAT) enzyme activities, and production of capsaicin in the cell suspension culture of Maraş-1 pepper seeds was determined. TDZ was applied in four levels $(0,0.1 \mathrm{mM}, 0.2 \mathrm{mM}, 0.4 \mathrm{mM})$ and at three times (days 8,10, and 12) to the cell suspensions. The content of the capsaicin in suspended cells was identified by high-performance liquid chromatography after extraction with ethyl acetate. It was identified that TDZ had a variable effect on the capsaicin accumulation. The highest capsaicin content was determined by 84.859 $\mu \mathrm{g} / \mathrm{g}$ f.w. at $0.4 \mathrm{mM} \mathrm{TDZ} \mathrm{10d.} \mathrm{The} \mathrm{highest} \mathrm{increase} \mathrm{by}$ $181.48 \%$ at $0.2 \mathrm{mM} \mathrm{TDZ} 10 \mathrm{~d}$, the highestdecreaseby $49.83 \%$ at $0.4 \mathrm{mM} \mathrm{TDZ} 10 \mathrm{~d}$ was determined intotal phenolic amount. The total protein amount decreased at $0.4 \mathrm{mM}$ TDZ 8dand 12d. The highest SOD (457.983 enzyme units $/ g$ f.w.) and CAT (0.143 enzyme units $/ g$ f.w.) activities at $0.4 \mathrm{mM} \mathrm{TDZ} 8$ d, the lowest SOD (73.526 enzyme units $/ g$ f.w.) and CAT (0.030 enzyme units $/ g$ f.w.) activities at $0.2 \mathrm{mM} \mathrm{TDZ} 12 \mathrm{~d}$ were measured.
\end{abstract}

Keywords-Capsicum annuum, catalase, superoxide dismutase, TDZ.

\section{INTRODUCTION}

Capsicum аппиит $\mathrm{L}$. is an economically important crop plant belonging to the family Solanaceae. Two main consumption types of pepper, spice and vegetable, that are prevalent throughout the world [1]. Capsicum species are well-known because of many medicinal properties. Chilies contain numerous chemicals including steamvolatile oil, fatty oils, carotenoids, vitamins, protein, fiber, and mineral elements [2, 3]. Aditionally, Capsicum contains capsaicinoid alkaloids specific to the genus Capsicum, which show many pharmacological properties [4]. As medicine, it is used as a counter irritant or pain relief in lumbago, neuralgia, rheumatic disorders, nonallergic rhinitis, diabetic neuropathy, osteoarthritis, and mouth sores [5, 6, 7]. Apart from this, chilies also possess in vitro antitumor-promoting activities and synergistic antimutagenic properties $[8,9]$. Thus, capsaicin is considered to be a potential chemical for pharmaceutical industries.

The secondary metabolites are known to play a major role in the adaptation of plants to their environment and also represent an important source of pharmaceuticals [10]. The developing field of plant biotechnology may provide a better alternative for the large scale production of secondary metabolites. The use of plant cell and tissue cultures for the large-scale production of secondary metabolites has so far achieved only limited success due to the low and unreliable yields of the products [11]. Various strategies have been developed to improve the production of secondary metabolites. This means that the maximization of the production and accumulation of secondary metabolites [12]. Elicitation is the induction of secondary metabolite production by either biotic or abiotic treatments [13].

Capsaicin is produced by separation and purification of the free cells [10]. Capsicum plants to be used for the synthesis of capsaicin normally take 4-5 months to grow. Therefore, Capsicum free and immobilized cell cultures can be an important way to obtain capsaicin [10,14].

Thidiazuron (TDZ), a substituted phenlyurea (N-phenyl1,2,3-thidiazol-5-yl urea), is a potent plant growth regulator that exhibits auxin- and cytokinin-like activity in various culture systems $[1,15]$. A number of physiological and biochemical events in cells are induced or enhanced by TDZ [15]. It induces diverse morphogenic responses, ranging from tissue proliferation to induction of shoot buds and somatic embryos [16, 17]. Also, TDZ is 
known for stimulating strong shoot proliferating activity in several plant species $[18,19,20]$.

We investigated capsaicin production and some physiological parameters of Capsicum annuum L. affected by TDZ elicitor.

\section{MATERIALS AND METHODS}

\subsection{Plant material}

Seeds of Capsicum annuum L. (Maraş-1) were obtained from the Eastern Mediterranean Transitional Zone Agricultural Research Station.

\subsection{Culture conditions}

Seeds of C. annuum L. were sterilized with $70 \%$ ethanol for $3 \mathrm{~min}$ and sodium hypochlorite for $20 \mathrm{~min}$, followed by washing with sterile distilled water. C. annuum seedlings were germinated in Murashige and Skoog [21]'s medium without hormones. Hypocotyl explants of the seedlings were placed into MS medium with $0.1 \mathrm{mg} / \mathrm{L}$ kinetin, $1 \mathrm{mg} / \mathrm{L} \mathrm{2,4} \mathrm{D,3 \%}$ sucrose and $0.7 \%$ agar to produce callus tissue at $25{ }^{\circ} \mathrm{C}$. They were subcultured two times and placed into liquid medium (MS without agar) to produce cell suspensions in $100 \mathrm{~mL}$ Erlenmeyer flasks. The cultures were incubated on a shaker at $110 \mathrm{rpm}$ and $25{ }^{\circ} \mathrm{C}$ [22].

\subsection{TDZ applications and Capsaicin Analysis}

Experiments were carried out in $100 \mathrm{~mL}$ Erlenmeyer flasks containing $40 \mathrm{~mL}$ of fresh medium. Each flask was inoculated with $1 \mathrm{~g}$ of fresh weight cells. After 14 days of growth, sterile TDZ $(0,0.1 \mathrm{mM}, 0.2 \mathrm{mM}, 0.4 \mathrm{mM})$ was added. The cultures were maintained on an orbital shaker at $25^{\circ} \mathrm{C}$ for 8,10 , and 12 days.

Cell samples were collected after incubation and analyzed for capsaicin. It was estimated by high-performance liquid chromatography assay based on the method of Sudha and Ravishankar [23]. Capsaicin from the culture media was extracted thrice with $20 \mathrm{ml}$ of ethyl acetate, each time in a separating funnel. The ethyl acetate layers were pooled and evaporated. The residue was dissolved in $1.0 \mathrm{~mL}$ of ethyl acetate for analysis. The extractions were filtered through a $0.45-\mu \mathrm{m}$ Millipore filter prior to injection on the HPLC. The capsaicin extracted from the callus and media was estimated by HPLC. The quantification of capsaicin was done on a C18 nucleosil column with detection at $280 \mathrm{~nm}$. The isocratic mobile phase was methanol: water (1\% acetic acid) $(39: 60 \mathrm{v} / \mathrm{v})$ and a flow rate of $1 \mathrm{ml} / \mathrm{min}$ was used [14].

\subsection{Physiological assays}

The total phenolic content of the callus was determined using the Folin-Ciocalteu assay [24]. The total protein amount was determined according to method of Bradford [25]. The superoxide dismutase (SOD) activity assay was based on the method of Beauchamp and Fridovich [26] and the catalase (CAT) activity was estimated according to the method of Bergmeyer [27].

\subsection{Statistical analysis}

Tukey's test was employed for statistical analysis using the SPSS 16.0 software package at the $P \leq 0.05$ level.

\section{RESULTS AND DISCUSSION}

The cell suspension samples capsaicin content of Capsicum annuum L. are shown in Fig. 1.

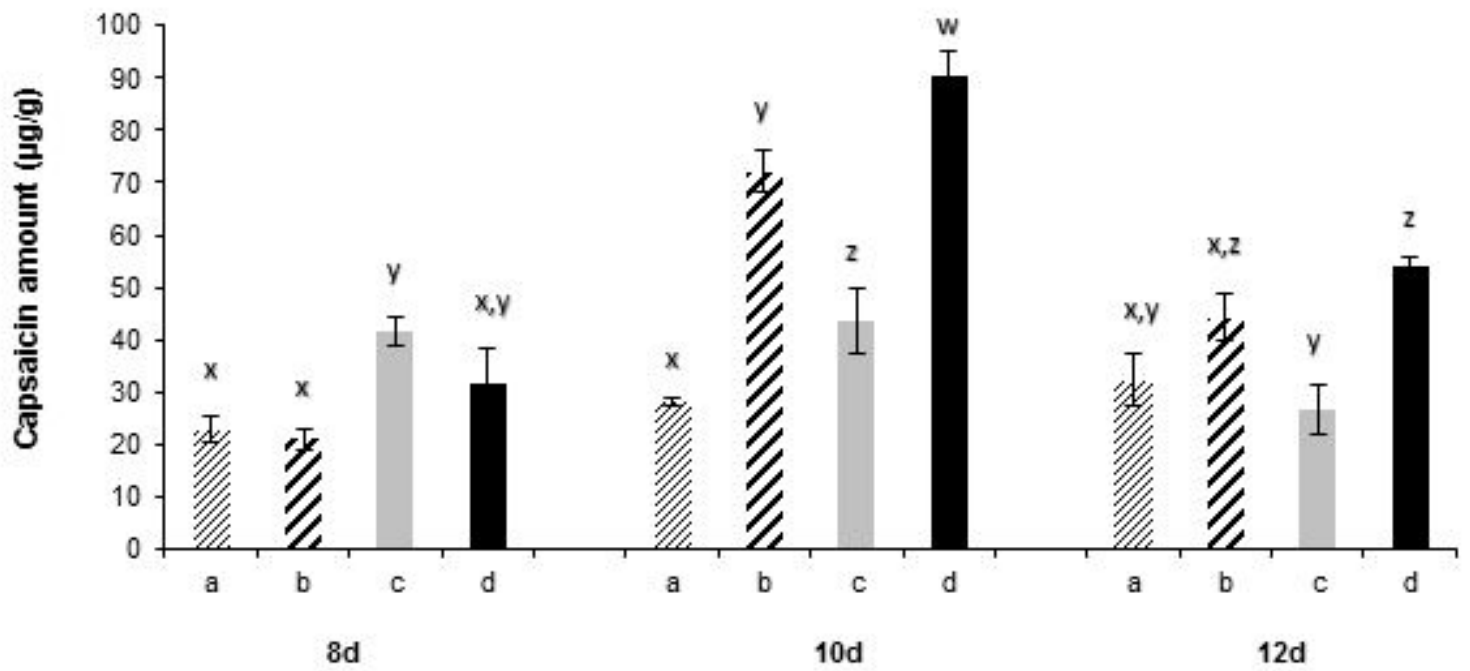

Fig. 1: Effect of TDZ on the amount of capsaicin in Capsicum annuum L. at different concentrations and times (a: Control, b: $0.1 \mathrm{mM} \mathrm{TDZ,} \mathrm{c:} 0.2 \mathrm{mM} \mathrm{TDZ,} \mathrm{d:} 0.4 \mathrm{mM} \mathrm{TDZ})$. Vertical bars represent $S E(n=3)$. Same letters are not significantly different at $P \leq 0.05$ (Tukey test) for each days. 
The change in the capsaicin amount of $C$. annuum L. at 8d was found between 21.095-41.649 $\mu \mathrm{g} / \mathrm{g}$ f.w. The capsaicin amount showed an increase with $0.2 \mathrm{mM}$ and $0.4 \mathrm{mM}$ TDZ at $8 \mathrm{~d}$ to the control $(\mathrm{P} \leq 0.05)$. The capsaicin content change was determined between 28.261-90.385 $\mu \mathrm{g} / \mathrm{g}$ f.w at 10d. The highest capsaicin accumulationat $10 \mathrm{~d}$ was $0.4 \mathrm{mM}$ TDZ. The difference between the control and $0.1 \mathrm{mM}, 0.2 \mathrm{mM}$ and $0.4 \mathrm{mM}$ TDZ was statistically significant $(\mathrm{P} \leq 0.05)$. The capsaicin content was found between 26.652-54.005 $\mu \mathrm{g} / \mathrm{g}$ fw at $12 \mathrm{~d}$. The highest value was found at $0.4 \mathrm{mM}$ TDZ $12 \mathrm{~d}$ (P $\leq 0.05)$. Considering the all concentrations and days, the highest amount was $90.385 \mu \mathrm{g} / \mathrm{g}$ f.w. at $0.4 \mathrm{mM}$ TDZ 10d, while the lowest amount was $21.095 \mu \mathrm{g} / \mathrm{g}$ f.w.at 0.2 $\mathrm{mM}$ TDZ $12 \mathrm{~d}$. There is no parallelism between the increase of capsaicin and TDZ (Fig. 1).
There are no studies regarding TDZ elicitor effect on capsaicin accumulation in the literature.Phenylpropanoid and valine biosynthesis metabolic pathways are the two methods of capsaicin biosynthesis. The first part of the aromatic biosynthesis pathway occurs through phenylpropanoid metabolism in all plants. This situation suggests that an elicitor application from outside advances the metabolic pathway in this direction. Transformation from vanillin and vanillylamine to capsaicin was found only in cell cultures of pepper and fruits [28]. According to this, it can be expressed that the TDZ compound effect on increasing the effect of the capsaicin amount is caused by the destruction of capsaicin or inhibitory activity with other molecules. The findings evidence that TDZ elicitor treatments enhances the effect on the accumulation of the capsaicin.

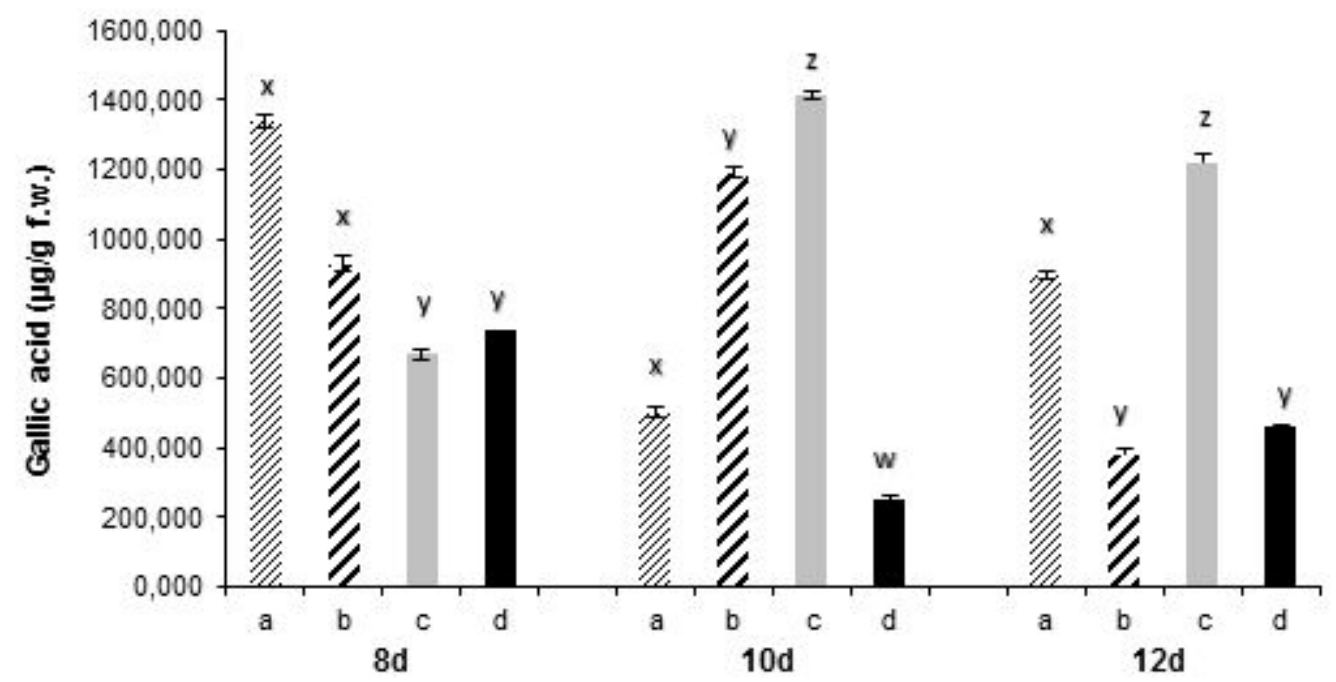

Fig. 2: Effect of TDZ on the amount of total phenolic in the cells of Capsicum annuum L. at different concentrations and times (a: Control, b: $0.1 \mathrm{mM} \mathrm{TDZ,} c: 0.2 \mathrm{mM} \mathrm{TDZ,} \mathrm{d:} 0.4 \mathrm{mM} \mathrm{TDZ).} \mathrm{Vertical} \mathrm{bars} \mathrm{represent} S E$ ( $n=3$ ). Same letters are not significantly different at $P \leq 0.05$ (Tukey test) for each days.

Capsaicin production increased with $0.2 \mathrm{mM}$ and $0.4 \mathrm{mM}$ TDZ at day 8 to the control, and the maximum increase was determined at $0.4 \mathrm{mM}$ TDZ $10 \mathrm{~d}$ and $12 \mathrm{~d}$. In contrast, the phenolic content was the opposite. The highest phenolic increase was determined at $0.2 \mathrm{mM}$ TDZ $10 \mathrm{~d}$ $(181.48 \%)(\mathrm{P} \leq 0.05)$ (Fig. 2). The highest capsaicin increase was determined at $0.4 \mathrm{mM}$ TDZ 10d (247.13\%) $(\mathrm{P} \leq 0.05)$ (Fig. 1), but the phenolic amounts decreased by $49.83 \%$ to the control at this concentration (Fig. 2).
Two pathways are involved in the biosynthesis of capsaicinoids: fatty acid metabolism and the phenylpropanoid pathway [29]. The phenolic structure comes from the phenylpropanoid pathway, in which phenylalanine is the precursor [30]. Estrada et al. [31] suggested that competition exists between the biosynthesis of capsaicinoids and other phenylpropanoid metabolites. Our results can be related with the idea. 


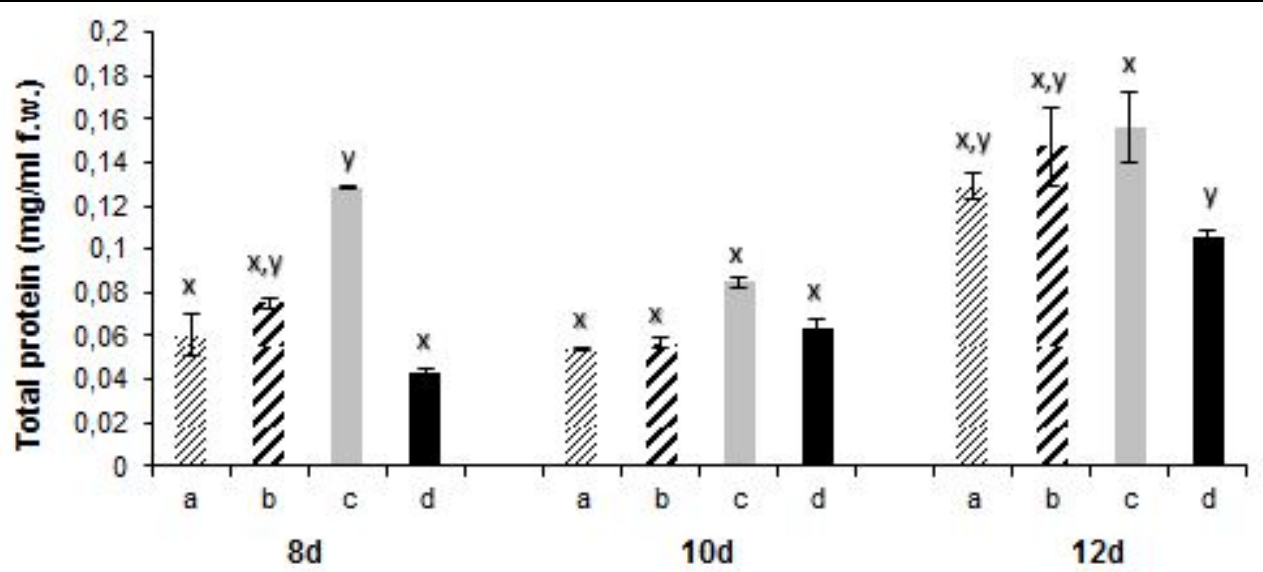

Fig. 3: Effect of TDZ on the amount of total protein in the cells of Capsicum annuum L. at different concentrations and times (a: Control, b: $0.1 \mathrm{mM} \mathrm{TDZ,} \mathrm{c:} 0.2 \mathrm{mM} \mathrm{TDZ,} \mathrm{d:} 0.4 \mathrm{mM}$ TDZ). Vertical bars represent $S E(n=3)$. Same letters are not significantly different at $P \leq 0.05$ (Tukey test) for each days.

In the present study, only $0.2 \mathrm{mM}$ TDZ $8 \mathrm{~d}$ treatment affects the change of total protein significantly $(\mathrm{P} \leq 0.05)$. In addition, $0.2 \mathrm{mM} \mathrm{TDZ}$ treatments were more effective than other treatments in increasing the total protein amount. The total protein amounts decreased to the control at $0.4 \mathrm{mM} \mathrm{TDZ} 8 \mathrm{~d}$ and $12 \mathrm{~d}$ (Fig. 3).

It is our opinion that TDZ stimulates protein synthesis. Klyachko et al. [32] and Ananiev et al. [33] observed that TDZ, 4-PU-30 and N6-benzylaminopurine accelerate polysome formation and stimulate RNA polymerase activity in pumpkin cotyledons, which supports this assumption. We have already mentioned that TDZ exhibits cytokinin-like activity in various culture systems. Cytokinins increase the total protein amount in maize and other plants too [34, 35, 36]. Moreover, cytokinins inhibit protein degradation by preventing protease and nuclease. Zavaleta-Mancera et al. [37] showed that cytokinins delay the oxidative process and using cytokinin increased the total protein in rice leaves.

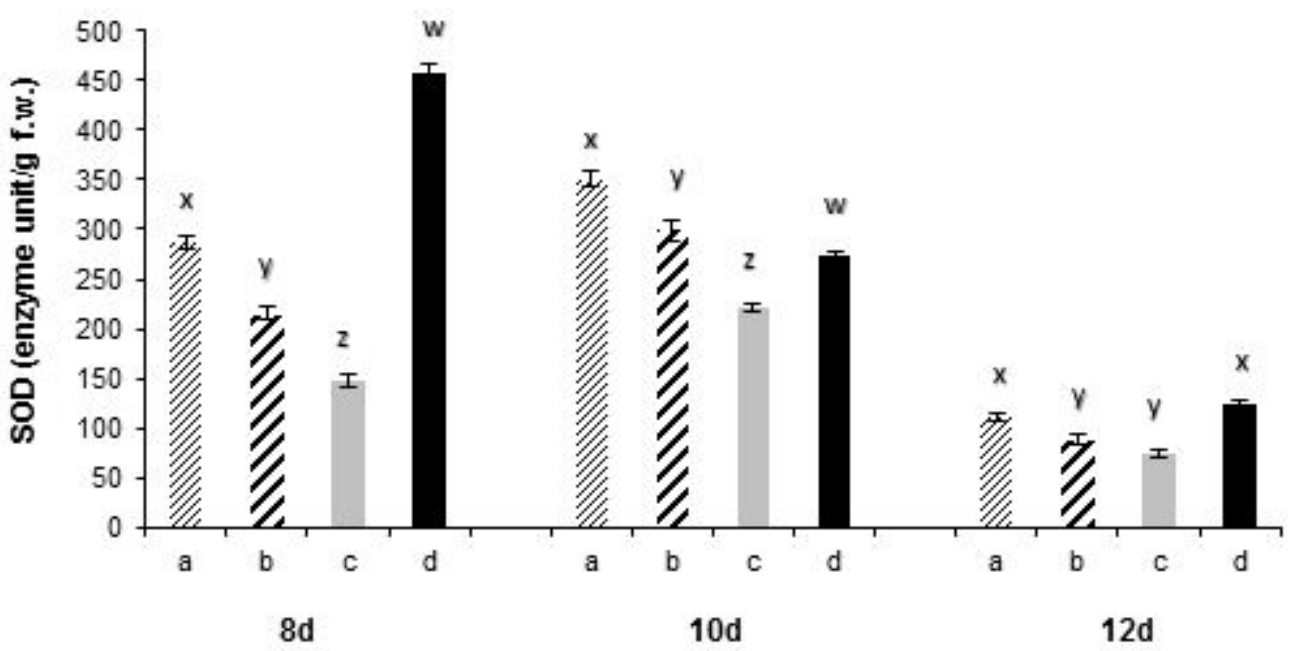

Fig. 4: Effect of TDZ on the activity of SOD enzyme in the cells of Capsicum annuum L. at different concentrations and times (a: Control, b: $0.1 \mathrm{mM} \mathrm{TDZ,} \mathrm{c:} 0.2 \mathrm{mM} \mathrm{TDZ,} \mathrm{d:} 0.4 \mathrm{mM}$ TDZ). Vertical bars represent $S E(n=3)$. Same letters are not significantly different at $P \leq 0.05$ (Tukey test) for each days.

The SOD activities of the pepper plants were decreased at $0.1 \mathrm{mM}$ and $0.2 \mathrm{mM} \mathrm{TDZ}$ of all treatment days and increased at $0.4 \mathrm{mM}$ TDZ $8 \mathrm{~d}$ and $12 \mathrm{~d}$ compared to the controls. The SOD responses were significant in all treatment groups except $0.4 \mathrm{mM}$ TDZ $12 \mathrm{~d}$. The highest rate of SOD activity was measured at $0.4 \mathrm{mM}$ TDZ $8 \mathrm{~d}$ (59.58\% increase compared to the control) and the lowest rate was measured at $0.2 \mathrm{mM} \mathrm{TDZ} 8 \mathrm{~d}(49.29 \%$ decrease compared to the control) (Fig. 4).

In the Pelargonium plants, after days 4 and 5 of the treatment, the control leaves showed significantly reduced the APX and SOD activities when compared with the initial stage [38]. In addition, the strongest SOD activity increase was detectedat the highest TDZ concentration in 
carnations [39]. The results of both studies are in agreement with our results.

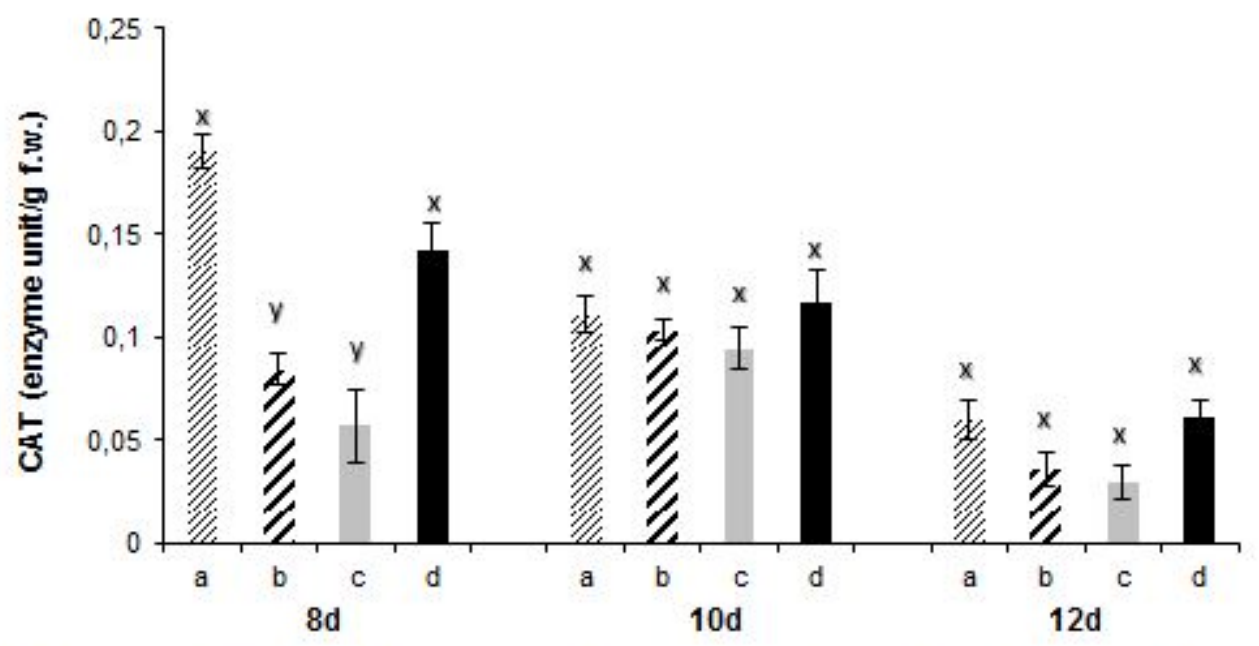

Fig. 5: Effect of TDZ on the activity of CAT enzyme in the cells of Capsicum annuum L. at different concentrations and times (a: Control, b: $0.1 \mathrm{mM} \mathrm{TDZ,} \mathrm{c:} 0.2 \mathrm{mM} \mathrm{TDZ,} \mathrm{d:} 0.4 \mathrm{mM} \mathrm{TDZ).} \mathrm{Vertical} \mathrm{bars} \mathrm{represent} S E(n=3)$. Same letters are not significantly different at $P \leq 0.05$ (Tukey test) for each days.

Another scavenger of $\mathrm{H}_{2} \mathrm{O}_{2}$, the CAT activity, decreased at $0.1 \mathrm{mM}$ TDZ and $0.2 \mathrm{mM}$ TDZ of all treatment days, and increased at $0.4 \mathrm{mM}$ TDZ $10 \mathrm{~d}$ and $12 \mathrm{~d}$ compared to the controls. Although significant decreases $(69.99 \%$ at $0.2 \mathrm{mM}$ TDZ and $55.58 \%$ at $0.1 \mathrm{mM}$ TDZ) were measured on day 8 , other groups exhibited slight and insignificant changes (Fig. 5).

Tang and Newton [40] determined TDZ influences on the antioxidant enzyme activity during the morphogenesis of eastern white pine. They showed that during the culture, the peroxidase (POD) activity decreased at the beginning and increased at later stages of the shoot bud formation and the CAT activity linearly decreased throughout the complete culture duration. All of these findings show that the TDZ-induced direct adventitious shooting in eastern white pine resulted in decreased activities of POD and CAT.

The abovementioned antioxidant enzymes play an important role in the detoxification of reactive oxygen species (ROS) produced under stressful conditions [41]. The role of ROS in plant growth and development is sustained by the interplay of ROS and plant growth regulators [42].

The concentration of plant growth regulators used is critical. When used with the appropriate concentrations of cytokinins, auxins and TDZ, it reduces the amount of SOD and CAT enzymes [43, 44]. In our results, the increase in the amount of protein and decrease in the amount of SOD and CAT enzymes at $0.1 \mathrm{mM}$ and 0.2 mM TDZ supports this view. Our results were the opposite with $0.4 \mathrm{mM}$ TDZ. This shows the importance of the concentration to be applied.
In our study, capsaicin production increased, and SOD and CAT amounts decreased at $0.1 \mathrm{mM}$ and $0.2 \mathrm{mM}$ TDZ. SOD converts superoxide radicals into hydrogen peroxide and molecular oxygen $\left(\mathrm{O}_{2}\right)$, while the CAT and POD convert hydrogen peroxide into water, and in the case of CAT, to oxygen and water [45]. Capsaicinoids are products of the phenylpropanoid and fatty acid synthesis pathways [46]. The POD activity had a negative association with the capsaicinoid amounts [47, 48]. This adverse relationship might be associated to the fact that POD activity is closely related to the oxidization of the capsaicinoid metabolism [49].

\section{CONCLUSION}

Capsaicin production is important for food and pharmaceutical industries. When capsaicin is produced by the traditional method, it takes a lot of time. To attain continuous and quick industrial production, the addition of stimulants to the growing medium will contribute to production of secondary metabolites. TDZ, when used in the appropriate concentration, in terms of both increasing the amount of capsaicin and not creating stress in plants, is found to be an important compound. On this topic, there are very few detailed studies. Furthermore, other enzymes in the biosynthetic pathway, and different concentrations of TDZ or TDZ in combination with other plant growth regulators, can be studied.

\section{ACKNOWLEDGEMENTS}

We are very grateful to the Research Fund of Nigde University (Project Number: FEB 2011/34-BAGEP) for financial support. 


\section{REFERENCES}

[1] H. Khan, I. Siddique andM. Anis, “Thidiazuron induced somatic embryogenesis and plant regeneration in Capsicum annuиm", Biol. Plantarum, 50, 789-792, 2006.

[2] P.W. Bosland and E.J. Votava, Peppers:vegetables and spice Capsicums. Crop Production Science in Horticulture, 12. CAB International Publishing, Wallingford, England, 2000.

[3] K. Sanatombi and G.J. Sharma,"Micropropagation of Capsicum frutescens L. using axillary shoot explants”, Sci. Hortic., 113, 96-99, 2007.

[4] J. Szolcsanyi, "Forty years in capsaicin research for sensory pharmacology and physiology", Neuropeptides,38, 377-384, 2004.

[5] C. Rains and H.M. Bryson, "Topical capsaicin: A review of its pharmacological properties and therapeutic potential in post-herpetic neuralgia, diabetic neuropathy and osteoarthritis", Drug Aging, 7, 317-328, 1995

[6] G.F. Barbero, A. Liazid, M. Palmaand C.G. Barroso,"Ultrasound-assisted extraction of capsaicinoids from peppers", Talanta, 75, 13321337, 2008.

[7] M. Hayman andP.C.A. Kam, “Capsaicin: A rewiew of its pharmacology and clinical applications”, Curr. Anaesth. Crit. Care, 19, 338-343, 2008.

[8] G.E. De Mejia, A. Quintanar-Hernandez and G. Loarca-Pina,"Antimutagenic activity of carotenoids in green peppers against some nitroarenes",Mutat. Res.416 (1-2), 11-19,1998.

[9] T. Maoka, K. Mochida, Y. Ito, Y. Fujiwara, K. Hashimoto, F. Enjo, M. Ogata, Y. Nabakuni, H. Tokuda and H. Nishino, "Cancer chemopreventive activity of carotenoids in the fruits of red paprika Capsicum annuum L.”, Cancer Lett., 172, 103-109, 2001.

[10] S.R. Rao and G.A. Ravishankar, "Plant cell cultures: Chemical factories of secondary metabolites", Biotech. Adv.,20, 101-153, 2002.

[11] N.Vijaya Sree, P.V.V. Udayasri, K.Y. Aswani, B.B. Ravi, K.Y. Phani and V.M. Vijay, "Advancements in the production of secondary metabolites", J. Nat. Prod., 3, 112-123, 2010.

[12] V. Mulabagal andH.S. Tsay,"Plant Cell Cultures An Alternative and Efficient Source for the Production of Biologically Important Secondary Metabolites”, Int. J. Appl. Sci. Eng., 2, 29-48, 2004.

[13]T.S. Johnson, G.A. Ravishankar and L.V. Venkataraman, "Elicitation of capsaicin production in freely suspended cells and immobilized cell cultures of Capsicum frutescens Mill.", Food Biotech.,5, 197-205, 1991.
[14]C. Islek, The effects of some elicitors on capsaicin production in freely suspended cells and immobilized cell cultures of Capsicum annuиm L. $\mathrm{PhD}$ Thesis. Ankara University, Ankara, Turkey (In Turkish), 2009.

[15]B. Guo, B.H. Abbasi, A. Zeb, L.L. Xu and Y.H. Wei, "TDZ: a multi-dimensional plant growth regülatör”. Afr. J. Biotech.,10, 8984-9000, 2011.

[16] A.A. Alatar, "Thidiazuron induced efficient in vitro multiplication and ex vitro conservation of Rauvolfia serpentina-a potent antihypertensive drug producing plant”, Biotechnol. Biotec. Eq., 29(3), 489-497, 2015.

[17]I. Siddique and M. Anis, "Rapid micropropagation of Ocimum basilicum using shoot tip explants precultured in thidiazuron supplemented liquid medium”, Biol. Plantarum, 51, 787-790, 2007.

[18]A. Dhavala, T.S. Rathore, "Micropropagation of Embelia ribes Burm f. through proliferation of adult plant axillary shoots", In Vitro Cell Dev. Bio. Plant.,46, 180-191, 2010.

[19]P. Kumar, D.K. Srivastava,"Effect of potent cytokinin thidiazuron on in vitro morphogenic potential of broccoli (Brassica oleracea L. var. italica), an important vegetable crop", Indian J. Plant Physiol. 20(4), 317-323, 2015.

[20]B. San,Y. Karakurt, F. Donmez, "Effects of Thidiazuron and Activated Charcoal on in vitro Shoot Proliferation and Rooting of Myrtle (Myrtus communis L.)”, J. Agric. Sci., 21(2), 177-183, 2015.

[21]T. Murashige andF. Skoog,"A revised medium for rapid growth and bio-assays with tobacco tissue cultures",Physiol. Plantarum, 15, 473-497,1962.

[22]C. Islek ,A.S. Ustun and E. Koc,"The effects of cellulase on capsaicin production in freely suspended cells and immobilized cell cultures of Capsicum annuum L", Pakistan J. Bot, 46 (5), 18831887, 2014.

[23]G. Sudha and G.A. Ravishankar,"Influence of methyl jasmonate and salicylic acid in the enhancement of capsaicin production in cell suspension cultures of Capsicum frutescens Mill.", Curr. Sci. India, 85, 1212-1217, 2003.

[24] V.L. Singleton andJ.A. Rossi, “Colorimetry of total phenolics with phosphomolybdic-phosphotungstic acid reagents", Am. J. Enol. Vitic., 16, 144-158, 1965.

[25] M. Bradford, "A rapid and sensitive method for quantation of microgram quantities of proteins utilizing the principle of protein dye binding"Anal. Biochem., 72, 248-250, 1976.

[26]C. Beauchamp andI. Fridovich,"Superoxide Dismutase: Improved assay and applicable to 
acrylamide gels",Anal. Biochem.,44, 276-287, 1971.

[27]N. Bergmeyer, Methoden der enzymatischen Analyse. Vol.1 Akademie Verlag, Berlin, 1970.

[28] N. Sukrasno and M.M. Yeoman, "Phenyl propanoid pathway metabolism during growth and devolepment of Capsicum frutescens fruits", Phytochemistry, 32, 839-844, 1993.

[29] N. Ochoa-Alejo, J.E. Gómez-Peralta, Activity of enzymes involved in capsaicin biosynthesis in callus tissue and fruits of chili pepper (Capsicum annuиm L.)”, J. Plant Physiol., 141, 147-152, 1993.

[30] Y. Sung, Y.Y. Chang and N.L. Ting,"Capsaicin biosynthesis in water-stressed hot pepper fruits", Bot. Bull. Acad. Sinica, 46, 35-42, 2005.

[31]B. Estrada, F. Pomar, J. Díaz, F. Merino and M.A. Bernal, "Pungency level in fruits of the Padrón pepper with different water supply", Scientia Hortic.,81,385-396, 1999.

[32] N. Klyachko,I. Schramm andO. Kulaeva O, "Effect of thidiazuron and cartolin on polysome formation and growth of pumpkin cotyledons", Fiziologia Rastenii, 34, 319-323, 1987.

[33]E. Ananiev, L. Karagyozov and E.Karanov, "Effect of cytokinins on ribosomal RNA gene expression in excised cotyledons of Cucurbita pepo", Planta, 170, 370-378, 1987.

[34]G.A. Romanov, "Cytokinins and tRNAs: A new insight into the old problem", Fiziologia Rastenii,37, 1196-1210, 1990.

[35]E. Tsenova and V. Vassileva, Physiological effects of synthetic growth regulator PP thidiazuron (Dropp) in higher plants, In: Proc X Nat Conf. Fiziol. Na. Rast. Sofia. 8: 250-256, 1990.

[36]W.R. Woodson and A.S. Brandt, Role of the gynoecium in cytokinin-induced senescence of carnation petals, J. Am. Soc. Hortic. Sci., 116, 676679, 1991.

[37]H.A. Zavaleta-Mancera, H. Lopez-Delgado,H. LozaTavera, M. Mora-Herrera, C. Trevilla-Garcia, M. Vargas-Suarezand H. Ougham,"Cytokinin promotes catalase and ascorbate peroxidase activities and preserves the chloroplast integrity during darksenescence", J. Plant Physiol., 164, 1572-1582, 2007.

[38] M. Hatami, A. Hatamzadeh, M. Ghasemnezhad andR.H. Sajedi,"Antioxidant enzymatic protection during Pelargonium plant leaf senescence is mediated by thidiazuron", Trakia J. Sci.,11(2), 152, 2013.

[39] T. Genkov and I. Ivanova,"Effect of cytokinin-active phenylurea derivatives on shoot multiplication, peroxidase and superoxide dismutase activities of in vitro cultured carnation”, Bulg. J. Plant Physiol.21(1), 73, 1995.

[40] W. Tang and R.J. Newton, "Plant regeneration rom callus cultures derived from mature zygotic embryos in white pine (Pinus strobus)" Plant Cell Rep., 24, $1-9,2005$.

[41]L. Hu, H. Li, H. Pang and J. Fu,"Responses of antioxidant gene, protein and enzymes to salinity stress in two genotypes of perennial ryegrass (Lolium perenne) differing in salt tolerance”, J. Plant Physiol., 169, 146-156, 2012.

[42] J.M. Kwak, V. Nguyen and J.I. Schroeder,"The role of reactive oxygen species in hormonal responses", Plant Physiol., 141, 323-329, 2006.

[43]P. Díaz-Vivancos, K. Majourhat, J.A. Fernández, J.A. Hernández and A. Piqueras, "Study of the antioxidant enzymatic system during shoot development from cultured intercalar meristems of saffron”, Plant Growth Regul., 65, 119-126, 2011.

[44] V.R. Parmar and Y.T. Jasrai, "Effect of thidiazuron (TDZ) on in vitro propagation of valuable medicinal plant: Uraria picta (jacq.) desv. ex dc.”, J. Agric. Res.,53(4), 513-521, 2015.

[45]C.J. Weydert AND J.J. Cullen, "Measurement of superoxide dismutase, catalase and glutathione peroxidase in cultured cells and tissue", Nat. Protocols, 5, 51-66, 2009.

[46]E. Blum, M. Mazourek, M.A. O'Connell, J. Curry, T., Thorup, K. Liu, M.M. Jahn and I.Paran, "Molecular mapping of capsaicinoid biosynthesis genes and quantitative trait loci analysis for capsaicinoid content in Capsicum",Theor. Appl. Genet., 108, 79-86, 2003.

[47]M. Contreras-Padilla and E.M.Yahia,"Changes in capsaicinoids during development maturation and senescence of chile pepper and relation with peroxidase activity", J. Agr. Food Chem.,46,20752079, 1998.

[48] Y. Di, J.J. Jiang,J.C. Shih, "The recent research of metabolism physiology in capsaicinoid", China Veget.3, 48-50, 2000.

[49] J.M. Zapata,A.A. Calderón, R. Muñoz, A. Ros Barceló, "Oxidation of natural hydroxybenzoic acids by grapevine peroxidases: kinetics characteristics and substrate specificity”, Am. J. Enol. Vitic.,43, 134-138, 1992. 